\title{
CHEMICAL AND NUTRITIONAL CHARACTERISTICS OF HIGH-FIBRE RYE MILLING FRACTIONS
}

\author{
Piotr Kołodziejczyk ${ }^{1 凶}$, Agnieszka Makowska , Barbara Pospieszna², \\ Jan Michniewicz ${ }^{1}$, Hanna Paschke ${ }^{1}$ \\ ${ }^{1}$ Institute of Food Technology of Plant Origin, Poznań University of Life Sciences \\ Wojska Polskiego 31, 60-624 Poznań, Poland \\ 2Department of Tourism and Recreation, Adam Mickiewicz University in Poznań \\ Bogumiła Krygowskiego 10, 61-680 Poznań, Poland
}

\begin{abstract}
Background. Many studies have demonstrated the potential health benefits of consuming more high-fibre cereal-based food products. Therefore, there is a need to discover new ways to improve the overall nutritional balance of refined cereal products and focus on increasing their dietary fibre content, at the expense of readily digestible carbohydrates.

Material and methods. Lab-scale milling and sieving of whole rye grain was used to obtain two fractions rich in dietary fibre. The fractions were analysed and compared, in terms of microstructure, chemical composition and nutritional quality.

Results. The two fractions significantly obtained differed in their particle size and contents of minerals, available saccharides, and nutritional fractions of starch and dietary fibre and its major components. The total dietary fibre concentrations in the coarse and fine fractions were 50.0 and $36.0 \mathrm{~g} / 100 \mathrm{~g}$, respectively, i.e. three and 2.2 times higher than that of wholegrain rye flour. Both fractions also differed in their relative proportions of major fibre components. In the fine fraction, the levels of soluble fibre, as well as soluble arabinoxylans and fructans, were significantly higher than those in the coarse fraction.

Conclusions. It was shown that the application of a simple dry-fractionation method to wholemeal rye flour allows the preparation of two rye products which can serve as concentrated sources of dietary fibre low in available saccharides.
\end{abstract}

Keywords: rye grain, dry fractionation, high-fibre milling fraction, dietary fibre components, proximate composition, nutritional quality

\section{INTRODUCTION}

Many studies have shown the relationship between a high intake of dietary fibre (DF) and the reduced risk of developing many lifestyle-related ailments (Slavin, 2003; Ye et al., 2012). According to the current recommendations of the European Food Safety Authority, the average daily requirement of DF is $25 \mathrm{~g}$ per day for an adult (EFSA, 2010). Many nutritionists and diet experts suggest that about $20-30 \%$ of this amount should be soluble (SDF) (Elleuch et al., 2011). In a large number of developed Western countries, a deep asymmetry is observed between recommendations for the daily intake of DF, and the low consumption of cereal products rich in DF amongst the general population (Slavin, 2003). This is due to the fact that 
in these countries, including Poland, most cereal-based food products are made with refined kernel endosperm from which the peripheral layers are excluded, despite the fact that these anatomical parts of the kernel have significant nutritional potential and contain most of the DF, micronutrients and phytochemicals of the kernel (Slavin, 2003). Therefore, there is a need to develop new high-fibre cereal products which are attractive to consumers, including cereal-based food ingredients that could be universally recommended as part of a healthful diet.

Among commonly grown cereals, especially in Poland, rye seems to be the best raw material for this type of cereal product, as it has a high DF content in its major components, such as arabinoxylan and fructan (Bach Knudsen and Lærke, 2010; Hansen et al., 2003; Karppinen et al., 2003). Although the $\beta$-glucan content of rye is lower than that of barley and oats, it is still almost twice as high as that of wheat (Wood, 2010). Due to the high levels of FRU and the water-soluble fraction of arabinoxylan, rye contains large amounts of SDF. In addition, rye DF components are accompanied by a number of bioactive compounds such as phenolic acids, alkylresorcinols, lignans, phytosterols, minerals and vitamins like tocopherols, tocotrienols and folates etc. (Slavin, 2003; Nyström et al., 2008). It is well documented that the major components of rye DF are mainly located in the outer layers of the kernel, which consists of the outer and inner pericarp, the testa, the hyaline layer and the aleurone and subaleurone layers (Glistø and Bach Knudsen, 1999; Härkönen et al., 1997).

To prepare cereal-based products with enhanced levels of DF or its single components (e.g. $\beta$-glucan or arabinoxylan), many different wet and dry fractionation technologies have been developed. Wet processes pose many technological problems, and they are expensive (Izydorczyk et al., 2006). Dry fractionation processes are more sustainable and economically more attractive. They are based on progressive grinding of cereal grains, wholegrain flour or bran to decrease the particle size, and then separating the fractions which contain most of the peripheral tissues rich in DF. Many experiments have verified the usefulness and efficiency of various grain pre-treatments before milling or grinding (e.g. tempering, cryogenic pre-treatment, degerming, dehulling, peeling, pearling etc.), different grinders and mills (e.g. roller, impact, hammer, ball, abrasive, cryogenic, ultrasonic etc.) and sorting techniques (e.g. sieving, air-classification, electrostatic separation etc.; Hemery et al., 2007). A combination of wet and dry technologies has also been used (Nordlund et al., 2013b). Most of these studies are related to wheat, barley and oats, but only a few have focused on dry fractionation of rye (Glistø and Bach Knudsen, 1999; Härkönen et al., 1997; Nordlund et al., 2012; 2013a). However, some of these innovative technologies require costly, high-tech specialised equipment, such as superfine milling installations, cryogenic mills or free-fall electrostatic separators.

The purpose of the present study was to evaluate the potential of a simple dry fractionation method using milling and sieving to obtain rye fractions enriched in DF. The chemical composition of the obtained highfibre products was determined and their nutritional quality was evaluated.

\section{MATERIAL AND METHODS}

\section{Materials and sample preparation (grinding and sorting)}

The commercial hybrid rye grain cultivar 'Visello', harvested in 2011 in Poland, was used in this study. We chose only one variety, based on three-year pilot studies from our laboratory. Cleaned grains tempered to a moisture content of $14.5 \%$ were milled with a laboratory roller mill (Quadrumat Senior, Brabender $\mathrm{GmbH}$, Germany) at the default settings. The obtained wholemeal flour (WF) was additionally passed once through break rollers and then twice through reduction rollers of the mill without sieving. The received fine WF was separated in a sieve shaker (AS $200 \mathrm{Ba}-$ sic, Retsch GmbH, Germany) on a sieve with $50 \mathrm{~mm}$ openings to produce a coarse fraction $1 \mathrm{~B}(\geq 50 \mathrm{~mm})$ and a fine endosperm rich fraction $1 \mathrm{~A}(<50 \mathrm{~mm})$ for $15 \mathrm{~min}$. The fraction 1A was discarded, whereas the fraction $1 \mathrm{~B}$ was reground in a laboratory ball mill type6 (LZBM, Poland) for $180 \mathrm{~min}$. The porcelain ball and bowl diameters were $2.4 \mathrm{~cm}$ and $22.5 \mathrm{~cm}$ respectively, and the internal bowl depth was $22.5 \mathrm{~cm}$. The fraction $1 \mathrm{~B}$ was sieved again on a sieve with $50 \mathrm{~mm}$ openings into two subsequent fractions: $2 \mathrm{~A}(<50 \mathrm{~mm})$ and $2 \mathrm{~B}$ ( $\geq 50 \mathrm{~mm}$ ). The fraction $2 \mathrm{~A}$ was removed, whereas the fraction $2 \mathrm{~B}$ was separated on sieves with openings of 
Kołodziejczyk, P., Makowska, A., Pospieszna, B., Michniewicz, J., Paschke, H. (2018). Chemical and nutritional characteristics of high-fibre rye milling fractions. Acta Sci. Pol. Technol. Aliment., 17(2), 149-157. http://dx.doi.org/10.17306/J.AFS.2018.0559

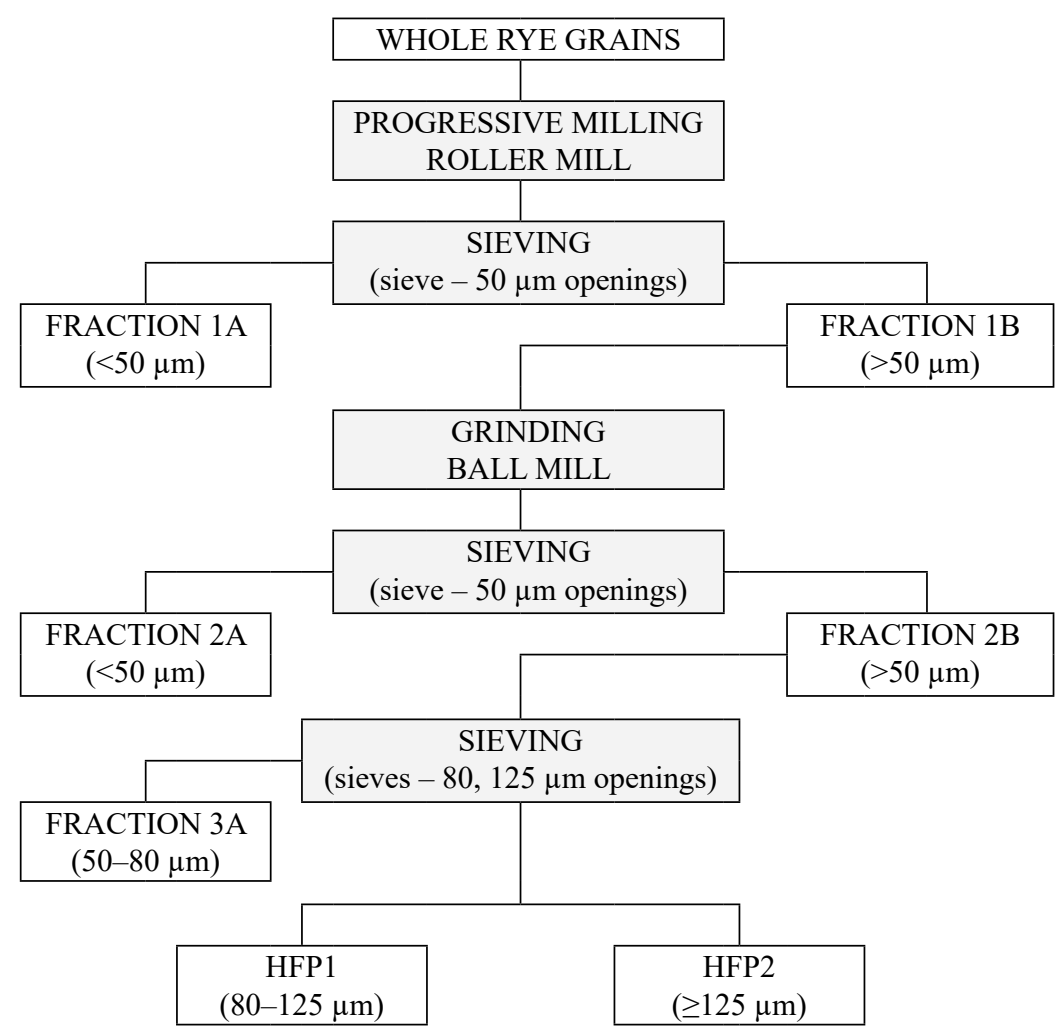

Fig. 1. Flow diagram of rye grain dry fractionation for the preparation of highfibre products

$80 \mathrm{~mm}$ and $125 \mathrm{~mm}$ into three fractions: 3A, HFP1 and HFP2. The fraction $3 \mathrm{~A}(50-80 \mathrm{~mm})$ was eliminated, while the HFP1 fraction $(80-125 \mathrm{~mm})$ enriched in SDF and the HFP2 fraction $(\geq 125 \mathrm{~mm})$ enriched in insoluble fibre (IDF) comprised the final products (Fig. 1).

\section{Analytical methods}

The main chemical components were determined according to AACC Approved Methods and ICC Standards: dry matter (ICC-Standard No. 110), ash (ICC-Standard No. 104), protein (AACC Approved Method 46-10), lipids (AACC Approved Method 30-10) and total starch (TS) (AACC Approved Method 76-13) (AACC, 2000; ICC, 1998). The contents of free glucose (FG), rapidly and slowly digestible starch (RDS and SDS respectively) and resistant starch (RS) were determined with the method described by Englyst et al. (1992), while total reducing saccharides, after twostep $80 \%$ methanol extraction, were colorimetrically determined using 3,5-dinitrosalicylic acid, according to the method described by the same authors. The AACC procedure was carried out to determine soluble fibre (SDF) and insoluble fibre (IDF) (AACC Approved Method 32-07) using the Megazyme total dietary fibre assay kit K-TDFR-200A (Megazyme International Ireland Ltd., Wicklow, Ireland). The total dietary fibre (TDF) content was calculated as a sum of SDF and IDF. The contents of DF components were determined as follows: total arabinoxylan (AX) and its water-soluble fraction (WE-AX) according to the method of Hashimoto et al. (1987), total $\beta$-glucan (BG) and its water-insoluble fraction (WUE-BG) according to the ICC Standard No. 168 and fructan (FRU) with the AACC Approved Method 32-32. The content of water-insoluble arabinoxylan (WUE-AX) was calculated as the difference between the contents of total $\mathrm{AX}$ and WE-AX, while the content of water-soluble $\beta$-glucan (WE-BG) was calculated as the difference between the total BG and WUE-BG contents. The BG 
and FRU contents were analysed using the Megazyme $\beta$-glucan mixed linkage and fructan assay kits, K-BG -LU and K-FRUC, respectively. The amount of total phenolic compounds (TPC) in the methanol extracts was determined using the Folin-Ciocalteu method according to Singleton et al. (1999). All analyses were run in triplicate.

\section{Microscopy}

The microstructure of HFP1 and HPF2 was examined by using the Q Imaging-Go3 camera and the Image-Pro Plus software Media Cybernetics.

\section{Statistical analysis}

The results are presented as mean \pm standard deviations. For multiple comparisons, one-way analysis of variance (ANOVA) was used. Differences between means were tested for significance using Duncan's multiple range test (MRT). Significance was set at $p \leq 0.05$. The statistical analysis was performed using the statistical software Statistica 8.0 (StatSoft Inc., USA).

\section{RESULTS AND DISCUSSION}

\section{Grinding and sieving}

The developed procedure made it possible to gradually increase the ratio of particles originating from the outer kernel tissues rich in DF (fractions 1B and 2B) to particles from the inner tissues rich in starch (fractions $1 \mathrm{~A}, 2 \mathrm{~A}$ and $3 \mathrm{~A}$ ). The aim of progressive grinding in roller and ball mills was the fragmentation of the cellular structures, to release the maximum possible amount of starch granules. Next, the purpose of sieving on sieve with $50 \mathrm{~mm}$ openings was to remove starch (fractions $1 \mathrm{~A}$ and $2 \mathrm{~A}$ ). To increase concentration of outer tissues in the final fractions HFP1 and HFP2, sieves with openings of 80 and $125 \mathrm{~mm}$ were used. The $50 \mathrm{~mm}$ mesh screen was chosen because it allowed most of the rye starch granules to pass through. Verwimp et al. (2004) found that rye starch granules ranged from 10 to $40 \mathrm{~mm}$ in diameter with average particle size of $31 \mathrm{~mm}$. The best biomarkers for the presence of peripheral kernel tissues are phenolic acids, alkylresorcinols and phytic acid, while the marker of the presence of endosperm tissues is starch (Hemery et al., 2009). The authors concluded that the contents of ferulic acid dehydrotrimer and p-cumaric acid can be considered markers of the outer pericarp and aleurone layer respectively, and are therefore efficient tools for the quantification of kernel tissue proportions in wheat milling fractions. Furthermore, Zieliński et al. (2007) demonstrated that the total phenolic compound content in the pericarp with testa of rye kernel is almost double that in the endosperm. Based on these observations, the usefulness of the applied dry fractionation procedure was verified by the determination of the TS and TPC contents in all fractions and WF. The ratios of TS to TPC content were also calculated (Table 1). Exclusion of the endosperm rich fraction $1 \mathrm{~A}(<50 \mathrm{~mm})$ meant that the fraction 1B $(\geq 50 \mathrm{~mm})$ contained $31 \%$ less TS than the initial material, and the ratio of TPC to TS increased by approximately $50 \%$ compared to WF. A relatively large amount of TS in the coarse fraction 1B was the reason for regrinding it in a ball mill to release the rest of the starch granules from the cellular structures, and then sorting into two consecutive fractions; 2A (removed) and 2B. To further increase the concentration of outer kernel tissues, fraction $2 \mathrm{~B}$ was separated into three fractions: $3 \mathrm{~A}(50-80 \mathrm{~mm})$, HFP1 $(80-125 \mathrm{~mm})$ and HFP2 $(\geq 125 \mathrm{~mm})$. Fraction $3 \mathrm{~A}$ was

Table 1. Yield, content of total starch (TS) and phenolics compounds (TPC) and the ratios of TPC to TS in wholemeal flour and different fractions from dry fractionation process of rye grain

\begin{tabular}{lcccc}
\hline \multicolumn{1}{c}{ Products } & Yield, $\%$ & Total starch, $\%$ DM & Total phenolics FAE, mg\% & Ratio of TPC/TS \\
\hline 1 & 2 & 3 & 4 & 5 \\
\hline Roller mill & & & & $132^{\mathrm{c}} \pm 5$ \\
Wholemeal flour $(\mathrm{WF})$ & 100.0 & $59.8^{\mathrm{e}} \pm 0.5$ & $39^{\mathrm{a}} \pm 2$ & $1: 453$ \\
1A $(<50 \mu \mathrm{m})$ & $19.2 \pm 1.4$ & $88.8^{\mathrm{h}} \pm 1.0$ & $168^{\mathrm{d}} \pm 16$ & $1: 2278$ \\
$1 \mathrm{~B}(\geq 50 \mu \mathrm{m})$ & $80.8 \pm 1.4$ & $50.7^{\mathrm{d}} \pm 0.6$ & & $1: 302$ \\
\hline
\end{tabular}


Kołodziejczyk, P., Makowska, A., Pospieszna, B., Michniewicz, J., Paschke, H. (2018). Chemical and nutritional characteristics of high-fibre rye milling fractions. Acta Sci. Pol. Technol. Aliment., 17(2), 149-157. http://dx.doi.org/10.17306/J.AFS.2018.0559

Table 1 - cont.

\begin{tabular}{lcccc}
\hline \multicolumn{1}{c}{1} & 2 & 3 & 4 & 5 \\
\hline Ball mill & & & & \\
$2 \mathrm{~A}(<50 \mu \mathrm{m})$ & $16.6 \pm 0.8$ & $80.3^{\mathrm{g}} \pm 1.2$ & $87^{\mathrm{b}} \pm 3$ & $1: 923$ \\
$2 \mathrm{~B}(\geq 50 \mu \mathrm{m})$ & $64.2 \pm 0.8$ & $40.3^{\mathrm{c}} \pm 0.2$ & $213^{\mathrm{e}} \pm 9$ & $1: 189$ \\
$3 \mathrm{~A}(50-80 \mu \mathrm{m})$ & $21.8 \pm 0.9$ & $67.1^{\mathrm{f}} \pm 0.1$ & $122^{\mathrm{c}} \pm 7$ & $1: 550$ \\
$\mathrm{HFP} 1(80-125 \mu \mathrm{m})$ & $16.8 \pm 1.0$ & $38.1^{\mathrm{b}} \pm 0.5$ & $176^{\mathrm{d}} \pm 13$ & $1: 217$ \\
$\mathrm{HFP} 2(\geq 125 \mu \mathrm{m})$ & $25.6 \pm 0.6$ & $20.0^{\mathrm{a}} \pm 0.1$ & $287^{\mathrm{f}} \pm 11$ & $1: 70$ \\
\hline
\end{tabular}

Mean value \pm standard deviation.

FAE - ferulic acid equivalents.

Values in the same columns followed with the different letters are significantly different $(P \leq 0.05)$.
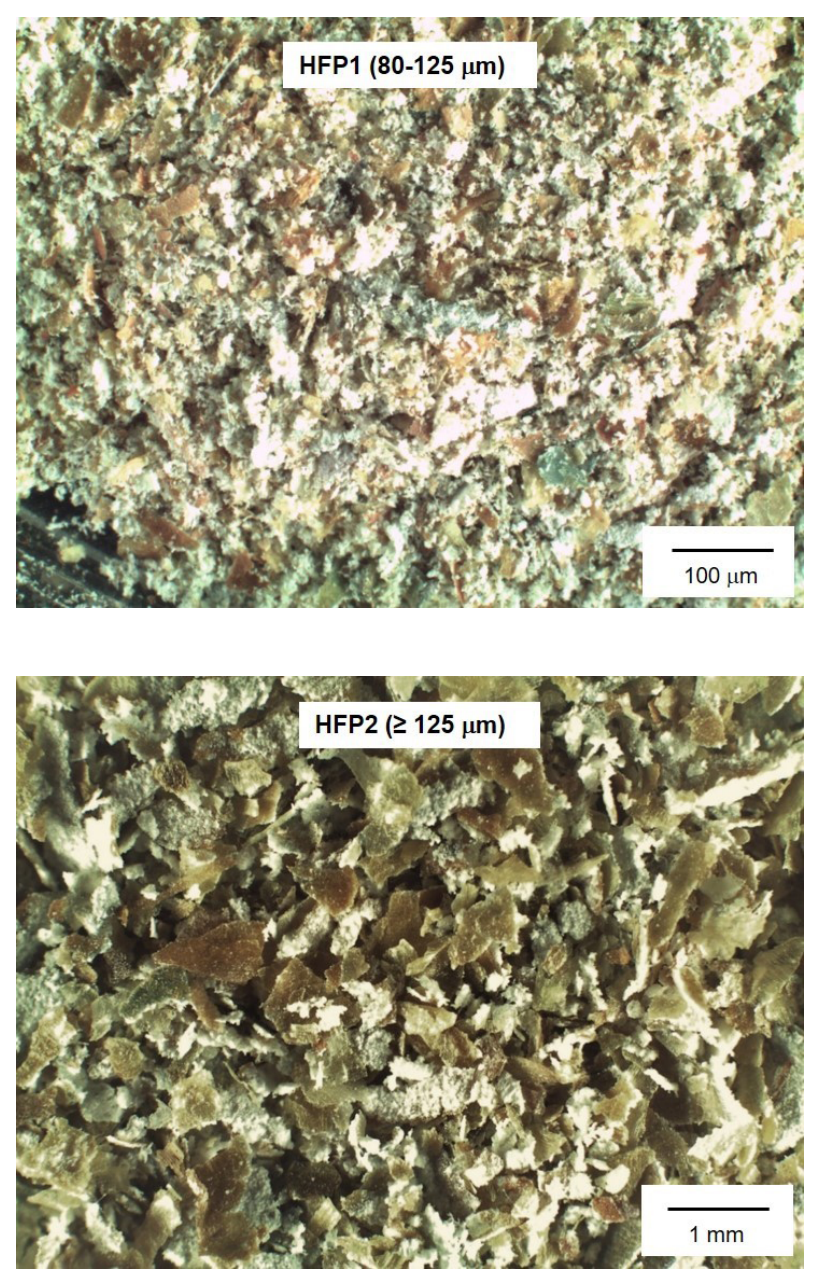

Fig. 2. Microstructure of high-fibre products (HFP1 and HFP2) imaged by stereomicroscope discarded, whereas the two other fractions, HFP1 and HFP2, yielded 16.8 and $25.6 \%$ of grain initial weight respectively, and had significantly lower TS contents and increased proportions of outer to inner tissue content when compared to WF. The residual TS contents in the HFP1 and HFP2 fractions, as a proportion of those originally present in the WF, were 10 and $8 \%$ respectively, whereas the ratios of TPC to TS in HFP1 and HFP2 were respectively double and 6.5-times higher than that in the raw material. The average particle sizes were $102 \mu \mathrm{m}$ and $427 \mu \mathrm{m}$ for the fine fraction HFP1 and the coarse HFP2 respectively.

\section{Microstructure}

High-fibre products (HFP1 and HFP2) were examined by stereomicroscope (Fig. 2). A comparison of the micrographs showed that both fractions differed in the composition of their particles. It was observed that HFP2 contained more lignified fragments of pericarp/ testa cell walls rich in DF components, and fewer particles consisting of starch-rich endosperm, in comparison to HFP1. The coarse fraction was similar to rye bran, while the fine fraction looked like the products of the final reduction passages of rye industrial milling.

\section{Dietary fibre and its components}

As expected, HFP1 and HFP2 differed significantly in their contents of TDF and its major components (Table 2). The coarse fraction and the fine fraction were respectively 2.7 and 1.8 times richer in TDF than the WF. However, the content of SDF in the HPF1 was twice as high as in HPF2. In both fractions, the AX 
Kołodziejczyk, P., Makowska, A., Pospieszna, B., Michniewicz, J., Paschke, H. (2018). Chemical and nutritional characteristics of high-fibre rye milling fractions. Acta Sci. Pol. Technol. Aliment., 17(2), 149-157. http://dx.doi.org/10.17306/J.AFS.2018.0559

Table 2. Content and composition of dietary fibre in wholemeal rye flour (WF) and high-fibre products (HFP1 and HFP2), \% of DM

\begin{tabular}{lccc}
\hline Dietary fibre and its components & WF & HFP1 & HFP2 \\
\hline Total dietary fibre (TDF) & $18.4^{\mathrm{a}} \pm 0.4$ & $33.1^{\mathrm{b}} \pm 0.8$ & $49.5^{\mathrm{c}} \pm 0.3$ \\
- soluble (SDF) & $3.9^{\mathrm{a}} \pm 0.1$ & $12.4^{\mathrm{c}} \pm 0.5$ & $5.8^{\mathrm{b}} \pm 0.3$ \\
- insoluble (IDF) & $14.5^{\mathrm{a}} \pm 0.4$ & $20.7^{\mathrm{b}} \pm 0.6$ & $43.7^{\mathrm{c}} \pm 0.4$ \\
Total arabinoxylan (AX) & $9.3^{\mathrm{a}} \pm 0.5$ & $15.4^{\mathrm{b}} \pm 0.9$ & $19.8^{\mathrm{c}} \pm 0.6$ \\
- water-soluble (WE-AX) & $4.0^{\mathrm{a}} \pm 0.1$ & $7.4^{\mathrm{b}} \pm 0.3$ & $3.7^{\mathrm{a}} \pm 0.3$ \\
- water-insoluble (WUE-AX) & $5.3^{\mathrm{a}} \pm 0.3$ & $8.0^{\mathrm{b}} \pm 0.5$ & $16.1^{\mathrm{c}} \pm 0.6$ \\
Total $\beta$-glucan (BG) & $2.1^{\mathrm{a}} \pm 0.1$ & $3.8^{\mathrm{b}} \pm 0.2$ & $4.1^{\mathrm{b}} \pm 0.2$ \\
- water-soluble (WE-BG) & $1.1^{\mathrm{a}} \pm 0.0$ & $1.5^{\mathrm{b}} \pm 0.1$ & $1.2^{\mathrm{a}} \pm 0.1$ \\
- water-insoluble (WUE-BG) & $1.0^{\mathrm{a}} \pm 0.1$ & $2.3^{\mathrm{b}} \pm 0.2$ & $2.9^{\mathrm{c}} \pm 0.1$ \\
Fructan (FRU) & $4.5^{\mathrm{a}} \pm 0.2$ & $7.2^{\mathrm{c}} \pm 0.1$ & $6.5^{\mathrm{b}} \pm 0.3$ \\
\hline
\end{tabular}

Mean value \pm standard deviation.

Values in the same columns followed with the different letters are significantly different $(P \leq 0.05)$.

were the quantitatively most significant DF components. The amounts of AX in HFP2 and HFP1 were greater than in the raw material, i.e. 2.1 and 1.7 times higher respectively. Moreover, HFP2 contained twice as much WUE-AX as HFP1, whereas the fine fraction was evidently richer in WE-AX. It is well known that WUE-AX is the primary structural cell wall component of the rye kernel pericarp/testa tissues, whereas WE-AX are mainly located in endosperm cell walls (Bach Knudsen and Lærke, 2010). The contents of BG did not differ significantly between the two fractions and were about twice as high as in WF. However, the difference between HFP1 and HFP2 was evident in the WE-BG contents. HFP1 was $20 \%$ richer in WE-BG than HFP2. Moreover, the fine fraction contained $10 \%$ more FRU than the coarse fraction. These significant differences may result from a dissimilar FRU to $\mathrm{AX}$ and $\mathrm{BG}$ distribution in the peripheral tissues of the rye kernel. Kuhlmann et al. (2002), analyzing rye milling products, showed that the fine bran obtained from reduction passages contained almost twice as much FRU as the raw material, while its content in the coarse bran obtained from break passages remained at a similar level to in the whole grain.

\section{Nutritional quality of the high-fibre products}

The contents of macronutrients in both fractions are summarised in Table 3. Both products were a good source of minerals and protein. The contents of minerals in HFP1 and HFP2, compared to the WF, were higher slightly; more than 1.5- and about 2.5-times respectively. It is expected that their addition to the human diet will significantly contribute to increased intake of the recommended macro- and microelements The protein contents in both fractions were similar, but about $70 \%$ higher compared to WF. Rye protein does not have a high biological value; however, the amount of protein originating from the peripheral layers of the kernel is several times higher than that of the endosperm. It is known that functional proteins are present in the external tissues of the rye kernel, whereas the majority of proteins in the inner endosperm are storage proteins. Similarly, there were no significant differences in the lipid contents in HFP1 and HFP2, but these were about $50 \%$ higher than in WF. This increase in fat content may be disadvantageous, as it reduces the shelf life of the product and raises its caloric value. On the other hand, it is preferable due to the higher content of unsaturated fatty acids, tocotrienols 
Kołodziejczyk, P., Makowska, A., Pospieszna, B., Michniewicz, J., Paschke, H. (2018). Chemical and nutritional characteristics of high-fibre rye milling fractions. Acta Sci. Pol. Technol. Aliment., 17(2), 149-157. http://dx.doi.org/10.17306/J.AFS.2018.0559

Table 3. Content of macronutrients in high-fibre products (HFP1 and HFP2), g/100 $\mathrm{g}$ of product as eaten

\begin{tabular}{lrr}
\hline \multicolumn{1}{c}{ Component } & HFP1 & HFP2 \\
\hline Water & $10.6^{\mathrm{a}} \pm 0.1$ & $10.7^{\mathrm{a}} \pm 0.1$ \\
Ash & $3.1^{\mathrm{a}} \pm 0.1$ & $4.9^{\mathrm{b}} \pm 0.2$ \\
Fat & $2.6^{\mathrm{a}} \pm 0.4$ & $2.7^{\mathrm{a}} \pm 0.2$ \\
Protein (N×6.25) & $16.1^{\mathrm{a}} \pm 0.4$ & $16.8^{\mathrm{b}} \pm 0.2$ \\
Total saccharides & $30.4^{\mathrm{b}} \pm 0.7$ & $21.0^{\mathrm{a}} \pm 0.4$ \\
- available saccharides & $29.2^{\mathrm{b}} \pm 0.5$ & $19.1^{\mathrm{a}} \pm 0.1$ \\
Total starch (TS) & $27.6^{\mathrm{b}} \pm 0.6$ & $17.9^{\mathrm{a}} \pm 0.1$ \\
- rapidly digestible starch (RDS) & $17.7^{\mathrm{b}} \pm 0.3$ & $10.7^{\mathrm{a}} \pm 0.2$ \\
- slowly digestible starch (SDS) & $8.7^{\mathrm{b}} \pm 0.3$ & $5.3^{\mathrm{a}} \pm 0.1$ \\
- resistance starch (RS) & $1.2^{\mathrm{a}} \pm 0.4$ & $1.9^{\mathrm{a}} \pm 0.2$ \\
Total reducing saccharides & $2.8^{\mathrm{a}} \pm 0.1$ & $3.1^{\mathrm{b}} \pm 0.1$ \\
- free glucose (FG) & $1.5^{\mathrm{a}} \pm 0.2$ & $1.6^{\mathrm{a}} \pm 0.0$ \\
Total dietary fibre (TDF)* & $36.0^{\mathrm{a}} \pm 0.4$ & $50.0^{\mathrm{b}} \pm 0.3$ \\
- soluble (SDF)* & $17.5^{\mathrm{b}} \pm 0.2$ & $11.0^{\mathrm{a}} \pm 0.3$ \\
\hline
\end{tabular}

Mean value \pm standard deviation.

Values in the same columns followed with the different letters are significantly different $(P \leq 0.05)$.

*The amounts of TDF and SDF include amounts of FRU.

and phytosterols accompanying these lipids in rye milling products (Slavin, 2003).

The main advantage of HFP1 and HFP2 was the low content of available saccharides, defined as the sum of available starches (RDS and SDS) and total reducing sugars, with a concurrent high TDF content. In $100 \mathrm{~g}$ of HFP2 as eaten, only $19.1 \mathrm{~g}$ of available saccharides were present, of which $56 \%$ was RDS. A significantly higher content of available saccharides was found in HFP1. It contained $29.2 \mathrm{~g} / 100 \mathrm{~g}$, of which $60 \%$ was RDS. The available starch content and the proportions of RDS in TS contents in HFP2 presented here were lower than those found in cereal bran. Englyst et al. (1996) showed that the contents of available starch in cereal brans ranged from 21.1 to $44.8 \mathrm{~g} / 100 \mathrm{~g}$ of product as eaten, whereas the proportions of RDS in the total available glucose contents of wheat, rye and oat bran was about $65 \%$. Moreover, the same authors analyzing the nutritionally important starch fraction contents of 39 starchy foods and glycaemic indices (GI) have reported a highly significant positive correlation between GI and both RDS and rapidly available glucose (RAG). A high RAG content in cereal-based products causes a rapid increase in plasma glucose and insulin levels after ingestion, which might be associated with several health complications, including diabetes, cardiovascular disease and obesity. For many people with diabetes, carbohydrate exchange is the most important element of meal planning. According to the Polish definition, one carbohydrate exchange $(1 \mathrm{CE})$ corresponds to $10 \mathrm{~g}$ of available carbohydrates. One serving (assumed to be $15 \mathrm{~g}$, i.e. one cup) of HFP1 delivers $0.5 \mathrm{CE}$, whereas HFP2 delivers only $0.3 \mathrm{CE}$. In comparison, one serving of wholegrain product, generally recommended in diets for overweight individuals and diabetics, contains about 1-1.5 CE. Moreover, Ragaee et al. (2011) found strong correlations between contents of both IDF and SDF and contents of both RDS and SDS in wheat breads enriched in fibre. The TDF content in $100 \mathrm{~g}$ of HFP2 as eaten was $50.0 \mathrm{~g}$, of which $11.0 \mathrm{~g}$ was the SDF, whereas in $100 \mathrm{~g}$ of HFP1 -36.0 and $17.5 \mathrm{~g}$ respectively. This means that approximately 3.5 cups of HFP 2 or 5 cups of HFP1 fully cover the recommended daily intake of TDF, as well as $75 \%$ and $170 \%$ of the required daily intake of SDF respectively. The amounts of the TDF and the SDF presented here in the both products include amounts of FRU, which is currently classified as a component of DF. The TDF content in HFP2 as well as the SDF content in HFP1 were significantly higher than those found in a previous study on rye bran (Nordlund et al., 2012; 2013a). Rye bran, eliminated during industrial milling of grains, is generally considered a concentrated source of DF and is often recommended by doctors and diet experts as part of a healthful diet. Kołodziejczyk and Michniewicz (2018) demonstrated that TDF contents in Polish commercial rye bran ranged from 23.2 to $36.2 \mathrm{~g} / 100 \mathrm{~g}$ of product as eaten, of which 7.5-8.2 $\mathrm{g}$ was SDF when FRU content was included.

\section{Potential application}

According to current EU regulations concerning highfibre products, to claim that a food product is "high in fibre" there should be at least $6 \mathrm{~g}$ of fibre per $100 \mathrm{~g}$ 
(or $3 \mathrm{~g}$ of fibre per $100 \mathrm{kcal}$; European Commission, 2006). The TDF contents in the both obtained rye fractions exceeded those required quantities several times over, which is why the fine fraction was called "high-fibre product 1 " and the coarse fraction "high-fibre product 2". The coarse fraction, as concentrated source of DF, especially of IDF, can be used as a potential additive to dairy products (e.g. milk, kefir, yogurt, buttermilk, etc.), as well as to soups, salads or muesli-type products. The fine fraction, with a very high SDF content, can be used as an additive to bread, pasta, muffins/cakes, extruded snacks, confectionery, etc. Moreover, HPF1 may be mixed with HFP2 with different quantitative ratios, while the obtained blend may be added to many food products as a concentrated source of IDF and/or SDF.

\section{CONCLUSIONS}

It was demonstrated that the application of a simple dry-fractionation method, using repeated milling and sieving of the wholemeal rye flour, allows the preparation of two fractions substantially enriched in DF. The coarse fraction, with an average particle size of $427 \mu \mathrm{m}$, and the fine fraction, with the average particle size of $102 \mu \mathrm{m}$, gave a satisfactory yield and respectively contained 50.0 and $36.0 \mathrm{~g}$ of TDF in $100 \mathrm{~g}$ of products as eaten, i.e. 3.0 and 2.2 times higher than that of wholegrain rye flour. Both fractions were characterized by various quantitative and qualitative compositions of the major components of DF. The TDF content in the coarse fraction, which had a higher concentration of outer kernel tissues, was accompanied by a rise in the amount of insoluble DF components. However, the fine fraction, which contained fewer pericarp/testa particles, had larger amounts of soluble DF. The high content of DF in the both fractions allows them to be considered high-fibre cerealbased products. Both high-fibre products, due to their advantageous nutrient composition, may be a valuable addition to the human diet, not only in terms of dietary fibre but also in minerals and protein. They may be useful in the prophylaxis and/or treatment of the socalled 'diseases of civilization'.

\section{REFERENCES}

AACC (2000). Approved methods of the AACC. $10^{\text {th }}$ ed., St. Paul, Minn.: AACC.

Bach Knudsen, K. E., Lærke, H. N. (2010). Rye arabinoxylans: Molecular structure, physicochemical properties and physiological effects in gastrointestinal tract. Cereal Chem., 87, 353-362.

EFSA (2010). Scientific opinion - scientific opinion on dietary reference values for carbohydrates and dietary fibre. EFSA J., 8, 1462.

Elleuch, M., Bedigian, D., Roiseux, O., Besbes, S., Blecker, C., Attia, H. (2011). Dietary fibre and fibre-rich by-products of food processing: Characterisation, technological functionality and commercial applications: Rev. Food Chem., 124, 411-421.

Englyst, H. N., Kingman, S. M., Cummings, J. H. (1992). Classification and measurement of nutrionally important starch fractions. Eur. J. Clin. Nutr., 46 (Suppl. 2), S33-S50.

Englyst, H. N., Veenstra, J., Hudson, G. J. (1996). Measurement of rapidly available glucose (RAG) in plant foods: a potential in vitro predictor of the glycemic response. Br. J. Nutr., 75, 327-337.

European Commission (2006). Regulation (EC) no 1924/2006 of the European Parliament and of the Council of 20 December 2006 of nutrition and health claims made on foods. OJ L, 404, 9-25.

Glistø, L. V., Bach Knudsen, K. E. (1999). Milling of whole grain to obtain fractions with different dietary fibre characteristics. J. Cereal Sci., 29, 89-97.

Hansen, B. H., Rasmussen, C. V., Bach Knudsen, K. E., Hansen, A. (2003). Effects of genotype and harvest year on contents and composition of dietary fibre in rye ( $\mathrm{Se}$ cale cereale L.) grain. J. Sci. Food Agric., 83, 76-85.

Hashimoto, S., Shogren, M. D., Pomeranz, Y. (1987). Cereal pentosans: their estimation and significance. I. Pentosans in wheat and milled wheat products. Cereal Chem., 64, 30-34.

Härkönen, H., Pessa, E., Suortti, T., Poutanen, K. (1997). Distribution and some properties of cell wall polysaccharides in rye milling fractions. J. Cereal Sci., 26, 95-104.

Hemery, Y., Rouau, X., Lullien-Pellerin, V., Barron, C., Abecassis, J. (2007). Dry processes to develop wheat fractions and products with enhanced nutritional quality. J. Cereal Sci., 46, 327-347.

Hemery, Y., Lullien-Pellerin, V., Rouau, X., Abecassis, J., Samson, M. F., Åman, P., ..., Barron, C. (2009). 
Kołodziejczyk, P., Makowska, A., Pospieszna, B., Michniewicz, J., Paschke, H. (2018). Chemical and nutritional characteristics of high-fibre rye milling fractions. Acta Sci. Pol. Technol. Aliment., 17(2), 149-157. http://dx.doi.org/10.17306/J.AFS.2018.0559

Biochemical markers: Efficient tools for the assessment of wheat grain tissue proportions in milling fractions. $\mathrm{J}$. Cereal Sci., 49, 55-64.

ICC - Standards (1998). Standard - Methods of the International Association for Cereal Chemistry (ICC). Detmold.

Izydorczyk, M. S., Biliaderis, C. G., Lazaridou, A. (2006). Cereal beta-glucans. In: C. G. Biliaderis, M. S. Izydorczyk (Eds.), Functional food carbohydrates (pp. 1-73). CRC Press, Taylor and Francis Group.

Karppinen, S., Myllymäki, O., Forssell, P., Poutanen, K. (2003). Fructan content of rye and rye products. Cereal Chem., 80, 168-171.

Kołodziejczyk, P., Michniewicz, J. (2018). Charakterystyka składu chemicznego i wartości żywieniowej handlowych otrąb żytnich dostępnych na polskim rynku [Chemical characterization and nutritional value of commercial rye bran available on the Polish market]. Przegl. Zboż.-Młyn., 62(2), 30-34 [in Polish].

Kuhlmann, T., Fretzdorff, B., Betsche,T., Ruppel, T. (2002). Fructan in Weizen und Roggen: Gehalte im Verlauf der Kornentwicklung, im Ganzkornn verschiedener Sorten und in den Mehlfraktionen. Getreide Mehl Brot., 56, 64-66.

Nordlund, E., Aura, A. M., Mattila, I., Kössö, T., Rouau, X., Poutanen, K. (2012). Formation of phenolic microbial metabolites and short-chain fatty acid from rye, wheat and oat bran and their fractions in metabolical in vitro colon model. J. Agric. Food Chem., 60, 8134-8145.

Nordlund, E., Heiniö, R. L., Viljanen, K., Pihlava, J. M., Lehtinen, P., Poutanen, K. (2013a). Flavour and stability of rye grain fraction in relation to their chemical composition. Food Res. Int., 54, 48-56.
Nordlund, E., Katina, K., Aura, A. M., Poutanen, K. (2013b). Changes in bran structure by bioprocessing with enzymes and yeast modifies the in vitro digestibility and fermentability of bran protein and dietary fibre complex. J. Cereal Sci., 58, 200-208.

Nyström, L., Lampi, A.-M., Andersson, A. A. M., Kamal-Eldin, A., Gebruers, K., Courtin, C. M., ..., Piironen, V. (2008). Phytochemicals and dietary fibre components in rye varieties in the HEALTHGRAIN Diversity Screen. J. Agric. Food Chem., 56, 9758-9766.

Ragaee, S., Guzar, I., Dhull, N., Seetharaman, K. (2011). Effects of fiber addition on antioxidant capacity and nutritional quality of wheat bread. Food Sci. Techn., 44, 2147-2153.

Singleton, V. L., Orthofer, R., Lamuela-Ravent, R. M. (1999). Analysis of total phenols and other oxidation substrates and antioxidants by means of Folin-Ciocalteu reagents. Meth. Enzym., 299, 152-178.

Slavin, J. (2003). Why whole grains protective: biological mechanisms. Proc. Nutr. Soc., 62, 129-134.

Verwimp, T., Vandeputte, G. E., Marrant, K., Delcour, J. A. (2004). Isolation and characterisation of rye starch. J. Cereal Sci., 39, 85-90.

Wood, P. J. (2010). Oat and rye $\beta$-glucan: properties and function. Cereal Chem., 87, 315-330.

Ye, E. Q., Chacko, S. A., Chou, E. I., Kugizaki, M., Liu, S. (2012). Greater whole-grain intake is associated with lower risk of type 2 diabetes, cardiovascular disease, and weight gain. J. Nutr., 142, 1304-1313.

Zieliński, H., Ceglińska, A., Michalska, A. (2007). Antioxidant contents and properties as quality indices of rye cultivars. Food Chem., 104, 980-988. 